\title{
Prevalence and intensity of genito-urinary schistosomiasis and associated risk factors among junior high school students in two local government areas around Zobe Dam in Katsina State, Nigeria
}

Tolulope Ebenezer Atalabi ${ }^{*}$, Umar Lawal ${ }^{1}$ and Simeon Johnson Ipinlaye $e^{1,2}$

\begin{abstract}
Background: The national burden of genito-urinary schistosomiasis in Nigeria has been expressed by an estimate of 101.3 million people at risk with an alarming figure of 29 million infected. Report obtained from respondents about Praziquantel ${ }^{\circledR}$ distribution and the obviously prevalent haematuria without any control programme in place justified the need for data on the prevalence, intensity of infection and associated risk factors which were the objectives this cross-sectional survey sought to address.
\end{abstract}

Methods: A total of 718 students aged 10-23 years from the study area were surveyed between May and August, 2015. Data on socio-demographic and risk factors were obtained using structured questionnaires. Clean universal bottles with corresponding labels were offered for sample collection between 10:00 am and 13:30 pm. Centrifuged samples were microscopically examined and intensity of infection was recorded per $10 \mathrm{ml}$ of each sample.

Results: Prevalence of genito-urinary schistosomiasis was $22.7 \%$ with a mean intensity of 25.05 ( \pm standard deviation, \pm 71.51 ) eggs/10 $\mathrm{ml}$ of urine. Higher prevalence $(19.5 \%)$ and mean intensity (28.7 eggs/10 $\mathrm{ml}$ of urine) was recorded among boys. Sex $\left(x^{2}=77.065, P<0.0001\right)$, age group $16-18\left(x^{2}=5.396, P=0.0202\right)$, altitude $\left(X^{2}=8.083\right.$, $P=0.0045)$, unwholesome water sources $\left(X^{2}=27.148, P<0.0001\right)$, human recreational activities $\left(X^{2}=122.437, P<0.0001\right)$, mothers' occupation $\left(X^{2}=6.359, P=0.0117\right)$, farming $\left(X^{2}=6.201, P=0.0128\right)$ and other brown collar jobs $\left(X^{2}=4.842\right.$, $P=0.0278$ in fathers' occupational category were found to be significantly associated with urogenital schistosomiasis. Boys were seven times more likely to be infected compared to girls [AOR (95 \% Cl): 7.3 (4.26-12.4)]. Age group 16-18 years was four times more likely to be infected compared to age group 10-12 years [AOR (95 \% Cl): 4.43 (2.62-7.49)]. Similarly, respondents with farming as fathers' occupation were twice more likely to be infected than those whose fathers were civil servants [AOR (95 \% Cl): 2.08 (1.2-3.59)].

Conclusions: Dutsin-Ma and Safana were classified as moderate-risk Local Government Areas (LGA). Sex, altitude, unwholesome water sources and mothers' occupation were identified as the determining epidemiological factors in the prevalence of the disease. Sustainable chemotherapeutic intervention with Praziquantel ${ }^{\circledR}$, good network of treated pipe-borne water, health education and waste disposal facilities are highly recommended to reduce its prevalence below the threshold of public health significance.

Keywords: Genito-urinary, Schistosomiasis, Risk factors, Prevalence, Intensity, Dutsin-Ma, Safana, Nigeria

\footnotetext{
* Correspondence: ebenezer2k2@gmail.com

'Department of Biological Sciences, Faculty of Science, Federal University,

Dutsin-Ma, P.M.B. 5001, Dutsin-Ma, Katsina State, Nigeria

Full list of author information is available at the end of the article
} 


\section{Background}

Globally, genito-urinary schistosomiasis remains a significant public health burden by consistently ranking a second position to malaria in terms of its socio-economic and public health importance [1]. It is closely associated with squalor-ravaged rural dwellers of tropical and sub-tropical regions of the world [2]. With the common knowledge that many endemic loci remain under-researched, researchers have underestimated the continental burden of the disease by reporting that 436 million and 112 million people, respectively, were at risk and infected in sub-Saharan Africa [3] by the cercariae of Schistosoma haematobium.

Various species of freshwater snail belonging to the genus Bulinus act as intermediate hosts of this aetiological agent. Disease transmission is further aided by various human water contact activities for recreational and domestic purposes [4]. Early symptoms of the disease include haematuria, anaemia and retardation of growth and development in children. At advanced stage, it results in cancer of the bladder, hepatic and renal malfunctions. In Africa, the morbidity of schistosomiases culminates in the mortality rate of an estimated 280,000 people per year [5].

In Nigeria, the burden of schistosomiasis has been expressed by an estimate of 101.3 million people who were at risk with an alarming figure of 29 million infected. The latter depicts Nigeria as the most endemic country in sub-Saharan Africa for schistosomiasis followed by Tanzania where 19 million people were infected [6].

The report obtained from respondents about Praziquantel $^{\odot}$ distribution as well as the obviously prevalent haematuria without any control programme in place justified the need for data on the prevalence, intensity of infection and associated risk factors which were the objectives this cross-sectional survey sought to address.

\section{Methods}

\section{Study area}

The survey was carried out in Safana $\left(12^{\circ} 24.5^{\prime} \mathrm{N}, 7^{\circ} 24.4^{\prime} \mathrm{E}\right)$ and Dutsin-Ma $\left(12^{\circ} 26^{\prime} \mathrm{N}, 7^{\circ} 29^{\prime} \mathrm{E}\right)$ Local Government Areas (LGAs) of Katsina State, Northwestern Nigeria. Covering a total area of $809 \mathrm{~km}^{2}$, both LGAs were inhabited by 353,450 people as at 2006 National Census [7]. Dutsin-Ma has a mean annual rainfall of $700 \mathrm{~mm}$ (May to September) and temperature range of 29-31 ${ }^{\circ} \mathrm{C}[8]$. The ethnic groups comprise the Hausa and Fulani who are predominantly cereal crop farmers, animal rearers and traders. Zobe Dam, the major water body, although located in the Western outskirt of the latter, is however, close to the eastern part of the former and boosts green revolution with irrigation capacity of 8000 ha [9].

\section{Study design, duration and respondents}

The cross-sectional study was carried out between May and August, 2015. It was designed to target a total number of 718 junior high school students from Darawa, Sokoto Rima, Kofa, Tsaskiyya, Kofa Fada and Safana communities.

Students in the age group 10-23 years voluntarily enrolled in the study. Meanwhile, student(s) who were severely ill, unwilling and those who either refused to return samples or supplied chemical in place of urine were not included in the survey.

A total of six schools was selected from the twenty junior high schools in both LGAs: Government Pilot Junior Secondary School (GPJSS), Safana; Government Junior Secondary School (GJSS), Tsaskiyya; Community Day Junior Secondary School (CDJSS), Safana; Government Pilot Junior Secondary School (GPJSS), Dutsin-Ma; Community Day Junior Secondary School (CDJSS), Dutsin-Ma and Government Junior Secondary School (GJSS), Dutsin-Ma. Sample size was allotted to each school and by extension, each class of participating students. Simple random sampling technique was employed to enrol 718 students from a total of about 4674 students in the selected schools.

\section{Sample collection and processing}

Forms A, B and C representing school-based, individualbased questionnaires and urine analysis forms, respectively, were used to collect data during the survey. The schoolbased questionnaire was administered to each principal. Among others, this was used to collect data on students' population, history of Praziquantel $^{\oplus}$ distribution, report of haematuria and local languages for haematuria and Bulinus species. Individual-based questionnaire was employed to collect information on name, age, sex, water sources and water contact activities such as swimming and playing in shallow water. The urinalysis form was used to record urine parameters.

Clean, screw-capped and labelled plastic universal bottles $(20 \mathrm{ml})$ were offered to the respondents who produced various quantities of terminal urine samples between the hours of 10:00 and 14:00 [10,11] which coincided well with the circadian rhythm of egg excretion in S. haematobium [12]. About $5 \mathrm{ml}$ of each urine sample was measured into test-tube and centrifuged at $2250 \mathrm{rpm}$ for $1.5 \mathrm{~min}$ using Centurion Scientific Centrifuge (C2 series). The supernatant fluid was decanted off while the sediment (containing eggs) was examined under light microscope.

Adjustable micro-pipette $(10-100 \mu \mathrm{l})$ was used to introduce $10 \mu \mathrm{l}$ of each sample onto a clean, grease free glass slide and covered at an angle with a glass slip to avoid bubble formation. Microscopic examination of wet preparation for the eggs of S. haematobium was carried out using $10 \times$ objective nose of 
Motic ${ }^{\bullet}$ Binocular Compound Light Microscope. Samples with eggs were recorded as positive while those without eggs were taken to be negative. For positive samples, egg counts were carried out and each average count was recorded as number of eggs per $10 \mathrm{ml}$ of urine sample [13]. Intensity of infection was categorised into light ( $<50$ eggs $/ 10 \mathrm{ml}$ of urine) and heavy ( $\geq 50$ eggs $/ 10 \mathrm{ml}$ of urine) infections [14].

\section{Quality assurance}

Each universal bottle was assigned a serial number which corresponded to the number on each individual-based questionnaire. Urine samples collected were promptly analysed at the sites of collection with the data on each reagent strip recorded within $90 \mathrm{~s}$. Where this was impossible, they were quickly transported to the Biology Laboratory of the Federal University, Dutsin-Ma. Noteworthy was the fact that accuracy and thoroughness might be compromised due to the stress of having to examine all the samples under the microscope. To circumvent this, a rapid means of screening out negative samples was adopted. Average counts of $S$. haematobium eggs were rather recorded. On few occasions where intensities were extremely light, averages of six or seven counts were recorded.

\section{Statistical analysis}

Data obtained from the survey were entered into Microsoft Excel 2010 and analysed with SPSS version 15.0. Data summary was carried out using frequency and crosstabs sections of descriptive statistics. Associations among variables were determined using Chi-square test and bivariate and multivariate logistic regression. Statistical significance was considered at $95 \%$ Confidence Level (CL) with a $P$-value of less than 0.05 . Strength of association was measured by means of Odds Ratio (OR) at $95 \%$ CI. Adjustment was made for OR by using haematuria.

\section{Results}

A total number of 718 junior high school students were enrolled for the survey. The mean age ( \pm standard deviation, $\mathrm{SD}$ ) of the respondents was $13.96 \pm 1.74$ years. White collar and brown collar jobs were the major occupational categories of the respondents' fathers (Table 1). Table 2 provides information on the sources of water for recreation and domestic uses among interviewees surveyed.

The highest (34.62 \%) and lowest (10.91\%) prevalence values were recorded among participants from Tsaskiyya and Local Government Educational Authority (LGEA) communities in Safana, respectively (Fig. 1). Meanwhile, the highest and lowest values of mean intensity were recorded among respondents from Kofa (44.26 eggs/10 ml
Table 1 Socio-demographic features of respondents from Safana and Dutsin-Ma LGAs

\begin{tabular}{llll}
\hline Variables & Frequency & Percentage & Cumulative percentage \\
\hline Age (years) & 126 & 17.5 & 17.5 \\
$10-12$ & 485 & 67.5 & 85.1 \\
$13-15$ & 94 & 13.1 & 98.2 \\
$16-18$ & 11 & 1.6 & 99.7 \\
$19-21$ & 2 & 0.3 & 100 \\
22-24 & & & \\
Sex & 401 & 55.8 & 44.2 \\
Male & 317 & 44.2 & 100 \\
Female & & & \\
Fathers' occupation & & 34.7 & 34.7 \\
White collar jobs & 249 & 16 & 50.7 \\
Farming & 115 & 48.9 & 99.6 \\
Other brown & 351 & & \\
collar jobs & & 0.3 & 99.9 \\
Late & 2 & 0.1 & 100 \\
Retiree & 1 & 100 & 100 \\
Mothers' occupation & & 10.6 & 10.6 \\
White collar jobs & 76 & 0.3 & 10.9 \\
Farming & 2 & 54.3 & 65.2 \\
Other brown & 390 & & \\
collar jobs & & & \\
Housewives & 250 & 318 & 100 \\
Total & & & \\
\hline
\end{tabular}

of urine) and Darawa (6.03 eggs/10 $\mathrm{ml}$ of urine) communities in Dutsin-Ma (Fig. 2).

The highest frequency of infection (50\%) was recorded among respondents who relied on dam water for domestic use, followed by 40.83 and $37.88 \%$ recorded among users of ponds and streams, respectively. However, the mean intensity of infection was highest among users of rivers [44.89 (2.71-87.08) eggs/10 $\mathrm{ml}$ of urine] followed by wells [34.44 (10.09-58.79)] and dams [24.21 (13.77-34.64)] (Table 3 and Fig. 3).

In the use of water for recreation, respondents who combined playing in shallow water with swimming had the highest frequency $(55.63 \%)$ and mean intensity [35.49 (14.73-56.25)] of S. haematobium infection. Swimmers recorded a second highest frequency and mean intensity of $10.13 \%$ and [20.67 (9.71-31.62) eggs/10 $\mathrm{ml}$ of urine], respectively (Table 3, Fig. 3).

In the bivariate analysis, dams [COR (95 \% CI): 3.63 (2.38-5.58)], ponds [COR (95 \% CI): 2.51 (1.56-4.04)], rivers [COR $(95 \% \mathrm{CI}): 2.03$ (1.06-3.84)], streams [COR (95 \% CI): $2.22(1.46-3.38)]$ and wells [COR (95 \% CI): $1.53(1.02-2.32)]$ were found to be significantly associated with the frequency of urogenital schistosomiasis. 
Table 2 Frequency of risk factors associated with Genito-urinary schistosomiasis from Safana and Dutsin-Ma LGAs

\begin{tabular}{|c|c|c|c|}
\hline Variables & Frequency & Percentage & Cumulative percentage \\
\hline \multicolumn{4}{|c|}{ Swimming experience } \\
\hline Yes & 237 & 33 & 33 \\
\hline No & 481 & 67 & 100 \\
\hline Total & 718 & & \\
\hline \multicolumn{4}{|c|}{ Playing in shallow water } \\
\hline Yes & 330 & 46 & 46 \\
\hline No & 388 & 54 & 100 \\
\hline Total & 718 & & \\
\hline \multicolumn{4}{|c|}{ Itching experience } \\
\hline Yes & 140 & 19.5 & 19.5 \\
\hline No & 578 & 80.5 & 100 \\
\hline Total & 718 & & \\
\hline \multicolumn{4}{|c|}{ Sources of water for drinking, cooking, washing \& bathing } \\
\hline Bore hole & 463 & 30.89 & 30.89 \\
\hline Dam & 174 & 11.61 & 42.5 \\
\hline Pond & 120 & 8.01 & 50.51 \\
\hline River & 53 & 3.54 & 54.05 \\
\hline Stream & 198 & 13.21 & 67.26 \\
\hline Well & 243 & 16.21 & 83.47 \\
\hline Tap & 246 & 16.4 & 99.87 \\
\hline Sachet & 2 & 0.13 & 100 \\
\hline Total & 1499 & 100 & \\
\hline
\end{tabular}

In the recreation aspect, only swimming combined with playing in shallow water [COR (95\% CI): 14.55 $(8.78-24.64)]$ was found to be significantly associated with the disease (Table 3).

Nevertheless, a weak linear relationship as well as a statistically significant association existed between egg counts of $S$. haematobium and swimming $(r=0.1752, P<0.0001)$, playing in shallow water $(r=0.1179, P=0.0016)$, fetching water from river $(r=0.08265, P=0.0268)$. A statistically insignificant association $(P=0.2641)$ coupled with a weak linear relationship $(r=0.04173)$, however, existed between egg count and fetching water from stream.

In this study, the prevalence of genito-urinary schistosomiasis was $22.7 \%$ with a mean ( \pm SD) intensity of $25.05 \pm 71.51)$ eggs $/ 10 \mathrm{ml}$ of urine. Of the 718 urine samples examined, $163(22.7 \%)$ tested positive for eggs of $S$. haematobium, with a total raw egg count (mean) of 4083 [25.05 (13.99-36.11)] (Table 4).

The prevalence and mean egg count (intensity) was higher in males $\left[19.5 \%\left(\chi^{2}=77.065, P<0.0001\right)\right.$ and 28.7 eggs $/ 10 \mathrm{ml}$ of urine)] than females $(3.2 \%$ and 2.83 eggs $/ 10 \mathrm{ml}$ of urine). The highest prevalence (14.9\%) was recorded among children in the age group 13-15 years $\left(\chi^{2}=7.857, P=0.0197\right)$ compared to age groups 10-12, 16-18, 19-21 and 22-24 years with prevalence rates of $3.06 \%, 4.04 \%, 0.56 \%$ and $0.14 \%$, respectively. However, as shown in Fig. 4, a seemingly highest mean intensity (28.91 eggs/10 $\mathrm{ml}$ of urine) was recorded for age group 10-12 years $\left(\chi^{2}=13.880, P=0.9978\right)$ compared to $13-15,16-18,19-21$, and $22-24$ years with mean intensities of 26.58, 20.28, 2 and $7 \mathrm{eggs} / 10 \mathrm{ml}$ of urine, respectively (Table 4). While there was insignificant association (0.9694) and weak linear relationship $(r=-0.0014)$ between age of respondents and S. haematobium egg counts, a statistically significant association $(P<0.0001)$ and weak linear relationship $(r=-0.3414)$ was recorded between the sex of respondents and egg counts of S. haematobium.

Of the total number of respondents infected, 146 $(89.57 \%)$ fell into the light intensity category while 17 (10.43\%) belonged to the heavy intensity category. By location, $90(55.21 \%)$ and $73(44.79 \%)$ of the infected respondents came from Dutsin-Ma and Safana LGAs, respectively. Conversely, of $4083 \mathrm{~S}$. haematobium eggs recovered, Dutsin-Ma recorded 2314 eggs (mean $=25.71$ (8.05-43.37) eggs/10 ml of urine)] while Safana recorded 1769 eggs $($ mean $=24.23(12.07-36.39)$ eggs $/ 10 \mathrm{ml}$ of urine]. Invariably, Dutsin-Ma recorded a higher prevalence of $12.53 \%$ and mean intensity.

Highest prevalence [12.12 \% $\left(\chi^{2}=7.236 ; P=0.0071\right)$ ] was recorded among children whose fathers' occupation belonged to the category of "other brown collar jobs" while the highest mean intensity [46.15 (-1.22-93.53) eggs/10 ml of urine)] of the infection was identified among children whose fathers' jobs fell into the category of "farming". As far as prevalence was concerned, the same scenario repeated for children whose mothers' occupations belonged to the category of "other brown collar jobs" with a highest prevalence of $\left[13.37 \%\left(\chi^{2}=100.523 ; P=0.0001\right)\right]$. The highest mean intensity $[33.17(6.44-59.89)$ eggs/10 ml of urine] was identified among children whose mothers were housewives, followed by other brown collar jobs [20.66 (11.63-29.68)] with civil servants as the least [15.71 (-0.27-31.69)] eggs/10 $\mathrm{ml}$ of urine (Table 4).

In the bivariate analysis, sex (boys) [COR (95\% CI): $6.86(4.28-10.99)$ ] and age group $16-18$ years [COR (95 \% CI): 2.11 (1.25-3.56)] were significantly associated with genito-urinary schistosomiasis. Meanwhile, altitude [COR (95 \% CI): 1.69 (1.18-2.45)] played a major role in the transmission of the infection unlike address [COR (95 \% CI): 1.01 (0.71-1.44)] whose role was insignificant. In fathers' occupational category, only farming [COR (95 \% CI): 1.93 (1.14-3.24)] and other brown collar jobs [COR (95 \% CI): 1.58 (1.05-2.39)] were found to be significantly associated with $S$. haematobium infection.

In mothers' occupational category, only other brown collar job [COR (95 \% CI): 3.22 (1.49-7.82)] and housewives [COR (95\% CI): $3.11(1.41-7.68)]$ were found to 


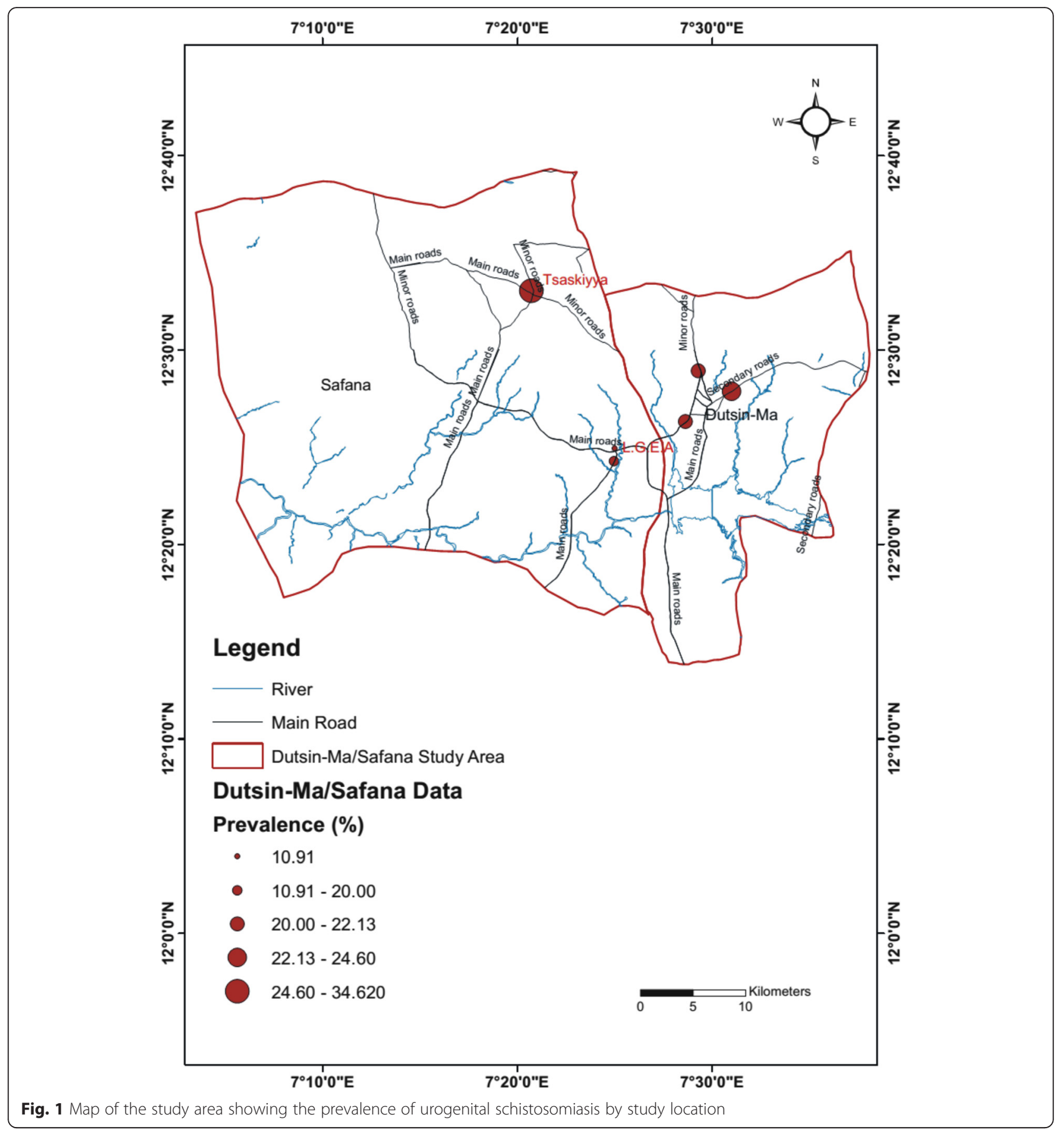

be significantly associated with the disease (Table 5). In the multivariate logistics regression analysis, only age and sex had statistically significant association with genitourinary schistosomiasis.

Boys [AOR (95 \% CI): 7.3 (4.26-12.4)] were seven times more likely to be infected with the cercariae of $S$. haematobium compared to girls. Moreover, age group 16-18 years [AOR (95 \% CI): 4.43 (2.62-7.49)] was about four times more likely to be infected compared to
$10-12$ years. Students whose fathers were farmers [AOR (95 \% CI): 2.08 (1.2-3.59)] were twice more likely to be infected than those whose fathers were civil servants (Table 5).

\section{Discussion}

Prevalence of genito-urinary schistosomiasis

In this cross-sectional survey, the overall prevalence of genito-urinary schistosomiasis among junior high school 


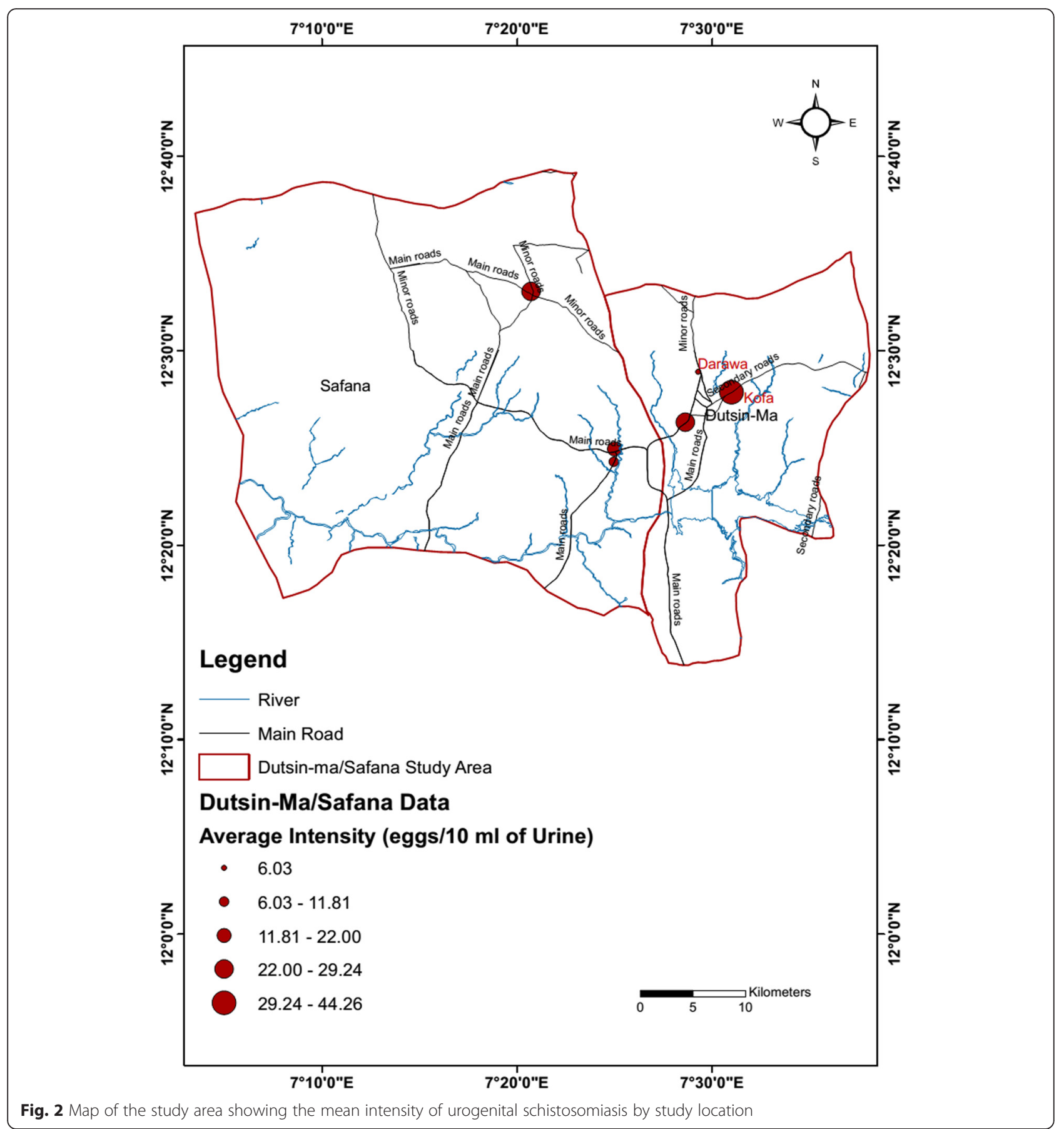

students from the LGAs was $22.7 \%$. They were categorised as moderate risk ( $\geq 10 \%$ but $<50 \%$ ) LGAs [15]. By logical deduction, water contact activities are expected to be higher in the middle belt and southern part of Nigeria compared to the North. This probably informed higher prevalences of $37.9 \%$ [16], $43.7 \%$ [17] and $55 \%$ [2] obtained in Cross River, Ondo and Benue States, respectively. Nevertheless, the prevalence obtained from this study is higher compared to $2.07 \%$ and $16.3 \%$ reported in Jos [18] and Nasarawa [19], respectively, both being North Central States. However, it is low compared to those obtained in Sokoto (37.7, 38.3 and $60.8 \%$ ) [20-22] and $61.7 \%$ obtained in Zamfara [23], all northwestern states of Nigeria. While a prevalence of $57.6 \%$ was recorded in Fatick region of Senegal [10], 52.8 \% was reported in north-eastern region of Zimbabwe [24]. Meanwhile, in highly endemic foci of Malawi, current data show that prevalence rates as high as $90-100 \%$ have been recorded among children aged five and 15 years [25]. 
Table 3 Frequency and intensity of genito-urinary schistosomiasis in relation to water sources for domestic and recreational uses

\begin{tabular}{llllll}
\hline Water source & Number examined (\%) & Number infected (\%) & Odds ratio (95 \% Cl) & $P$-value & ECAM (95 \% Cl) \\
\hline Borehole & $463(100)$ & $110(23.76)$ & $1.13(0.78-1.65)$ & 0.5052 & $2497[22.7(14.28-31.12)]$ \\
Dam & $174(100)$ & $87(50)$ & $3.63(2.38-5.58)$ & $<0.0001$ & $2106[24.21(13.77-34.64)]$ \\
Pond & $120(100)$ & $49(40.83)$ & $2.51(1.56-4.04)$ & 0.0001 & $819[16.71(10.55-22.87)]$ \\
River & $53(100)$ & $19(35.85)$ & $2.03(1.06-3.84)$ & 0.0274 & $853[44.89(2.71-87.08)]$ \\
Stream & $198(100)$ & $75(37.88)$ & $2.22(1.46-3.38)$ & 0.0002 & $1602[21.36(9.95-32.77)]$ \\
Well & $243(100)$ & $72(29.63)$ & $1.53(1.02-2.32)$ & 0.0406 & $2480[34.44(10.09-58.79)]$ \\
Tap & $246(100)$ & $53(21.54)$ & $1.00(0.65-1.54)$ & 1.0000 & $802[15.13(7.32-22.95)]$ \\
Sachet & $2(100)$ & 0 & 0 & - & 0 \\
Recreational activities & & & & \\
$\quad$ Swimming & $237(100)$ & $24(10.13)$ & $1.32(0.73-2.37)$ & 0.3523 & $496[20.67(9.71-31.62)]$ \\
Playing in shallow water & $330(100)$ & $26(7.88)$ & 1 & - & $397[15.27(1.45-29.09)]$ \\
Swimming \& playing in shallow water & $151(100)$ & $84(55.63)$ & $14.55(8.78-24.64)$ & $<0.0001$ & $2981[35.49(14.73-56.25)]$ \\
\hline
\end{tabular}

In the ECAM column, the raw egg counts are followed by the mean egg counts and the confidence intervals in parentheses

Abbreviation: ECAM Egg count arithmetic mean

The prevalence rates obtained in this study are highly informative. These are a function of the interplay of various factors ranging from ecological to socio-economic which in turn took toll on the water contact activities of the study population. To corroborate this, in Katsina State, as at 2010, 0.2 and $6.4 \%$ of the households used toilet on water and lacked toilet facility, respectively, while as at 2009, $23.6 \%$ households had their toilets within a distance of $500 \mathrm{~m}$. Moreover, as at 2009, mean annual rainfall of $473.8 \mathrm{~mm}$ and temperature range of 21.3-34.5 ${ }^{\circ} \mathrm{C}$ were recorded [7]. These factors limit the network of freshwater bodies and ensure that the few available become characteristically infested with $S$. haematobium larvae.

Furthermore, a higher prevalence of $19.5 \%$ was recorded in boys compared to $3.2 \%$ in girls after the study. Some researchers have previously documented higher prevalence rates in boys: (boys: $45.5 \%$; girls: $37.2 \%$ ) [26],

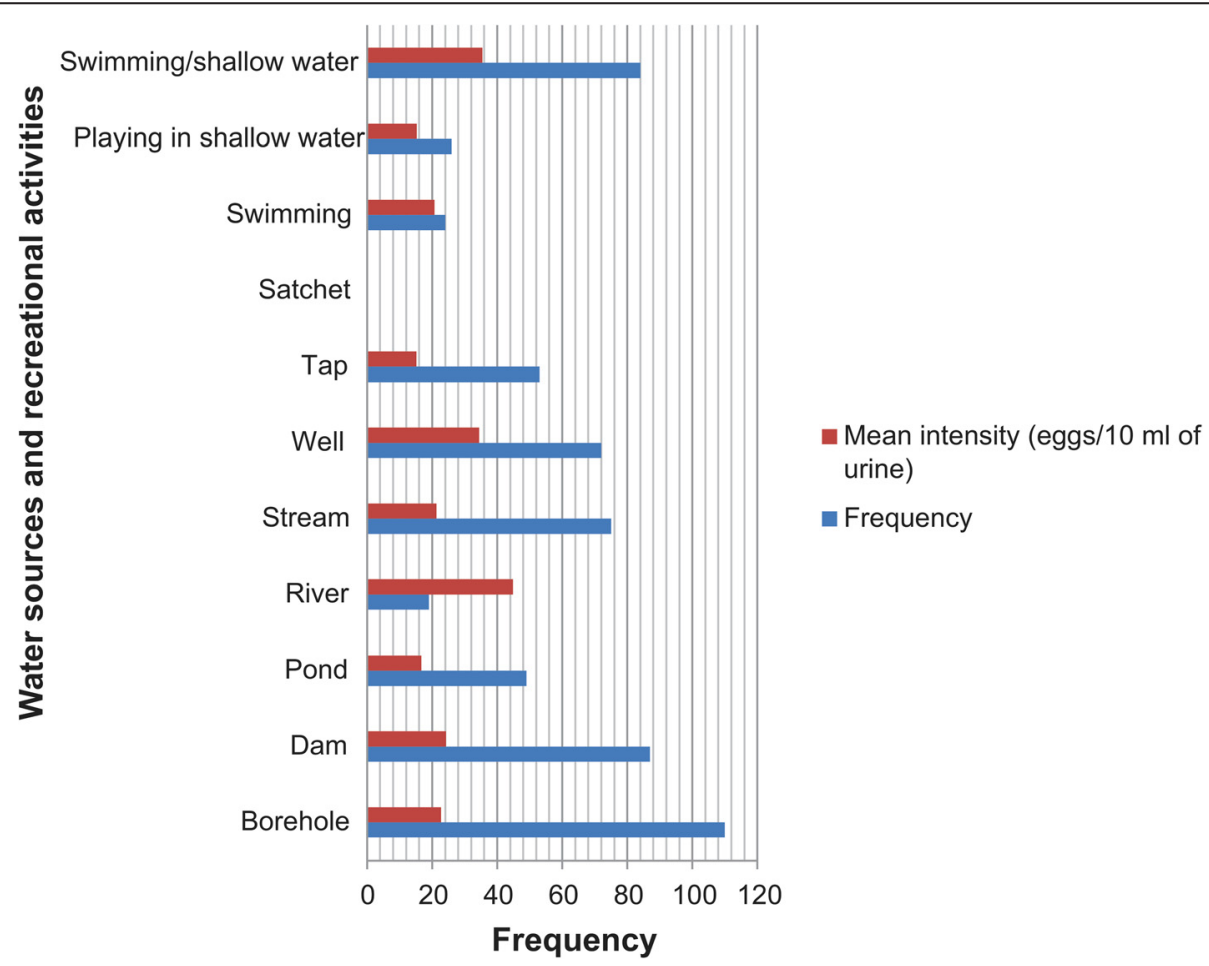

Fig. 3 Water sources/recreation-related frequency and intensity of infection with S. haematobium cercariae in the study LGAs 
Table 4 Prevalence and intensity of genito-urinary schistosomiasis in relation to sex, age, LGAs, category of S. haematobium infection and parental occupation of respondents

\begin{tabular}{|c|c|c|c|c|}
\hline Variables & $\begin{array}{l}\text { Number } \\
\text { examined }\end{array}$ & $\begin{array}{l}\text { Number } \\
\text { infected }\end{array}$ & $\begin{array}{l}\text { Prevalence } \\
(\%)\end{array}$ & $\begin{array}{l}\text { Raw egg count } \\
\text { [Mean }(95 \% \mathrm{Cl})]\end{array}$ \\
\hline \multicolumn{5}{|l|}{ Sex } \\
\hline Boys & 401 & 140 & 19.5 & $\begin{array}{l}4018 \\
{[28.7(15.9-41.49)]}\end{array}$ \\
\hline Girls & 317 & 23 & 3.2 & $\begin{array}{l}65 \\
{[2.83(1.71-3.95)]}\end{array}$ \\
\hline$x^{2}$ test & & & 77.065 & \\
\hline$P$-value & & & $<0.0001$ & $<0.05$ \\
\hline \multicolumn{5}{|l|}{ Age (years) } \\
\hline $10-12$ & 126 & 22 & 3.06 & $\begin{array}{l}636 \\
{[28.91(5.72-52.09)]}\end{array}$ \\
\hline $13-15$ & 485 & 107 & 14.9 & $\begin{array}{l}2844 \\
{[26.58(10.5-42.65)]}\end{array}$ \\
\hline $16-18$ & 94 & 29 & 4.04 & $\begin{array}{l}588 \\
{[20.28(9.71-30.84)]}\end{array}$ \\
\hline $19-21$ & 11 & 4 & 0.56 & 8 [2 (0.16-3.84)] \\
\hline $22-24$ & 2 & 1 & 0.14 & $7(7)$ \\
\hline$x^{2}$ test & & & 0.642 & - \\
\hline$P$-value & & & 0.4231 & 0.9981 \\
\hline \multicolumn{5}{|l|}{ Address } \\
\hline Safana & 320 & 73 & 10.17 & $\begin{array}{l}1769 \\
{[24.23(12.07-36.39)]}\end{array}$ \\
\hline Dutsin-Ma & 398 & 90 & 12.53 & $\begin{array}{l}2314 \\
{[25.71(8.05-43.37)]}\end{array}$ \\
\hline$P$-value & & & & 1.064 \\
\hline \multicolumn{5}{|l|}{ Infection category } \\
\hline $\begin{aligned} & \text { Light } \\
&(\leq 50 \text { eggs } / 10 \mathrm{ml})\end{aligned}$ & 146 & 146 & 20.33 & $\begin{array}{l}1543 \\
{[10.57(8.48-12.66)]}\end{array}$ \\
\hline $\begin{array}{l}\text { Heavy } \\
(\geq 50 \text { eggs/10 ml) }\end{array}$ & 17 & 17 & 2.37 & $\begin{array}{l}2540 \\
{[149.41(57.52-241.31)]}\end{array}$ \\
\hline$P$-value & & & & 0.2793 \\
\hline \multicolumn{5}{|l|}{ Fathers' occupation } \\
\hline Civil servants & 249 & 43 & 5.99 & $\begin{array}{l}571 \\
{[13.28(8.42-18.14)]}\end{array}$ \\
\hline Farmers & 115 & 33 & 4.59 & $\begin{array}{l}1523 \\
{[46.15(-1.22-93.53)]}\end{array}$ \\
\hline $\begin{array}{l}\text { Other brown } \\
\text { collar jobs }\end{array}$ & 351 & 87 & 12.12 & $\begin{array}{l}1989 \\
{[22.86(11.95-33.78)]}\end{array}$ \\
\hline Late (Dead) & 2 & 0 & 0 & 0 \\
\hline Retiree & 1 & 0 & 0 & 0 \\
\hline$P$-value & & & 0.0814 & 0.9995 \\
\hline \multicolumn{5}{|c|}{ Mothers' occupation } \\
\hline Civil servants & 76 & 7 & 0.97 & $\begin{array}{l}110 \\
{[15.71(-0.27-31.69)]}\end{array}$ \\
\hline Farmers & 2 & 0 & 0 & 0 \\
\hline $\begin{array}{l}\text { Other brown } \\
\text { collar jobs }\end{array}$ & 390 & 96 & 13.37 & $\begin{array}{l}1983 \\
{[20.66(11.63-29.68)]}\end{array}$ \\
\hline Housewives & 250 & 60 & 8.36 & $\begin{array}{l}1990 \\
{[33.17(6.44-59.89)]}\end{array}$ \\
\hline$P$-value & & & 0.0231 & 1.0000 \\
\hline Total & 718 & 163 & 22.7 & $4083(25.05)$ \\
\hline
\end{tabular}

(boys: 18.7 \%; girls: $8.11 \%$ ) [19], (boys: 37 \%; girls: $31.2 \%$ ) [27] and (boys: $8.2 \%$; girls: $5.2 \%$ ) [28]. However, the result of this survey contradicted the findings at Ebonyi (boys: 44.9 \%; girls: $51.9 \%$ ) [29] and Ogun (boys: $57.1 \%$; girls: $59.2 \%)$ [12] states in Nigeria. Another report of higher prevalence rate in females was given in Ogun State (boys: $22.4 \%$; girls: $23.2 \%$ ) [30] and Sudan (boys: $22 \%$; girls: $34 \%)$ [31].

These results were actually anticipated due to the focal nature of the infection. The higher prevalence rate recorded among boys is suggestive of more water contact activities like swimming, playing with shallow water and fishing, in addition to the normal duty of fetching water and washing which are peculiar to both sexes [2, 20, 26].

Prevalence increased with age as shown by this survey. However, the highest prevalence of $14.9 \%$ was recorded in the age group 13-15 years. This quite agrees with previous findings which reported high prevalences for $13-15$ years [13, 27]; $11-15$ years [2, 19]; $12-16$ years [32]; and $13-16$ years [33].

In this study, respondents who relied on unwholesome water sources recorded higher values of prevalence. Meanwhile, previous findings have shown that access to wholesome water sources was associated with significantly lower odds of infection with S. haematobium [34]. Lack of pure and potable water supply has been identified as a major factor in the spread of the disease [19]. This is further attested to by the report from Katsina State as at 2010 where $4.6 \%$ of households had access to treated pipe-borne water while $9.6 \%$ depended on rivers [7].

Finally, children whose parental occupation belonged to the category of brown collar jobs (farming and other brown collar jobs) suffered more from the menace of the disease. Respondents with fathers in this group had a prevalence of $16.71 \%$ while those with mothers in similar group had a prevalence of $13.37 \%$. In Ethiopia, a higher prevalence (56 \%) was reported among subjects whose fathers were farmers [11].

\section{Intensity of genito-urinary schistosomiasis}

In this survey, boys recorded a higher mean intensity (28.7 eggs/10 $\mathrm{ml}$ of urine) compared to girls (2.83 eggs/ $10 \mathrm{ml}$ of urine). This is consistent with previous reports: (boys: 9.36 eggs $/ 10 \mathrm{ml}$; girls: 7.81 eggs/10 ml) [11], (boys: 32 eggs $/ 10 \mathrm{ml}$; girls: 21.5 eggs $/ 10 \mathrm{ml}$ ) [18] and (boys: $45.45 \mathrm{eggs} / 10 \mathrm{ml}$; girls: $36.58 \mathrm{eggs} / 10 \mathrm{ml}$ ) [22]. This pattern of intensity suggests a higher frequency of contact with infested water bodies by boys through swimming, fishing, playing in shallow water and fetching water for construction work.

Moreover, mean intensity decreased with age. This could be explained by reduction in the frequency of water contact activities among older students as a result 


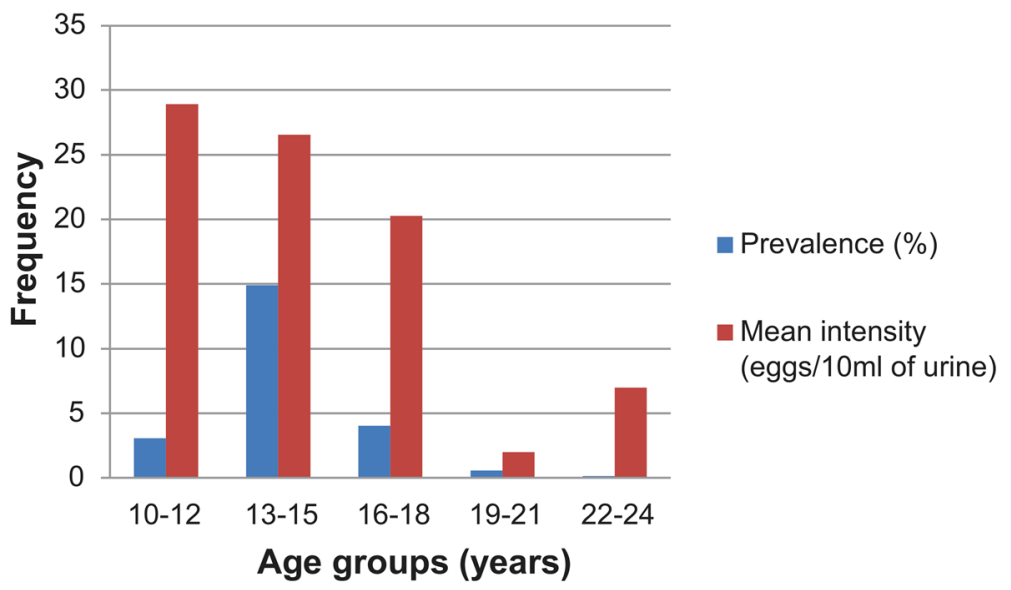

Fig. 4 Age group-related prevalence and intensity with urogenital schistosomiasis in the study LGAs

of maturity and acquisition of knowledge about the disease by formal education. In a study conducted in Nigeria, similar result was obtained [35]. Age group 10-12 years recorded the highest mean intensity (28.91 eggs/10 ml of urine) while age group 13-15 years, the second highest, recorded 26.58 eggs $/ 10 \mathrm{ml}$ of urine. In surveys conducted at Plateau and Ebonyi States of Nigeria, 10-14 years was reported as the age group with the highest intensity $[18,36]$.

A dramatic twist occurred in the pattern of mean intensity obtained in this study with respondents who adhered strictly to the usage of tap, well, borehole and sachet water sources recording the highest mean intensity of 55.78 eggs $/ 10 \mathrm{ml}$ of urine. Noteworthy was the fact that all the respondents had a previous experience of swimming in S. haematobium cercariae-infested water bodies. Respondents who, however, combined the habits of swimming with playing in shallow water bodies recorded the highest mean intensity ( $35.9 \mathrm{eggs} / 10 \mathrm{ml}$ of urine) in their category, with swimmers as the second highest (22.43 eggs/10 $\mathrm{ml}$ of urine). Previous studies have confirmed the possibility of $S$. haematobium infection in those who depended on wholesome water sources (for domestic use) subject to contact with unwholesome water sources for recreation. To corroborate this, mean intensity of 9.5 eggs $/ 10 \mathrm{ml}$ of urine was reported in interviewees who relied on borehole water for consumption [35]. The high rate of the infection in some villages supplied with tap water in Senegal was attributed to similar factor as well as the proximity to ponds, the lack of health education and poor hygiene [10].

A higher mean intensity (31.69 eggs $/ 10 \mathrm{ml}$ of urine) was recorded in Dutsin-Ma LGA compared to Safana LGA (19.66 eggs/10 $\mathrm{ml}$ of urine). This might be attributed to the location of Zobe Dam in the former, suggesting a stronger network of rivers, ponds and streams which is a key factor in the epidemiology of genitourinary schistosomiasis.
As far as infection category was concerned, 17 (2.37 \%) respondents of the whole 718 surveyed accounted for the heavy mean intensity of $149.41 \mathrm{eggs} / 10 \mathrm{ml}$ of urine recorded compared to 146 (20.33\%) subjects who accounted for a light mean intensity of 10.57 eggs $/ 10 \mathrm{ml}$ of urine. Previous studies have reported that majority of infected subjects belonged to the "light infection" category $[21,23,26]$. Interviewees whose fathers were farmers recorded the highest mean intensity $(46.21 \mathrm{eggs} / 10 \mathrm{ml}$ of urine) while those whose fathers' jobs belonged to the "other brown collar jobs" category served as the second highest (22.84 eggs/10 $\mathrm{ml}$ of urine). Again, this result agrees to the report of a survey conducted in Zamfara State, Nigeria [21]. Noteworthy is the fact that there is a dearth of literature addressing the intensity of infection among school children based on their parents' occupations. Conversely, in respondents whose mothers were civil servants, the highest mean intensity (39.33 eggs/ $10 \mathrm{ml}$ of urine) was recorded while those whose mothers were housewives served as the second highest (36.23 eggs/ $10 \mathrm{ml}$ of urine). It was previously reported that the disease was common among children whose mothers or fathers were civil servants [37]. However, no figure was given as regards the intensity of infection. Theoretically, such children were not expected to be infected. However, with the common knowledge that some civil servants are illiterates as well as potential brown collar jobs seekers, this result is justifiable.

\section{Relationship between genito-urinary schistosomiasis and some variables}

In this study, fathers' occupation (farming), sex and age were significantly associated with the disease. Respondents with farming as fathers' occupation were twice [AOR (95\% CI): 2.08 (1.2-3.59)] more likely to be infected compared to those whose fathers were civil servants. This is consistent with the findings of 
Table 5 Multivariate analysis of the variables associated with the frequency of genito-urinary schistosomiasis among respondents

\begin{tabular}{|c|c|c|c|c|c|}
\hline Variables & Subtotal & Positive (\%) & Negative (\%) & COR $(95 \% \mathrm{Cl})$ & AOR $(95 \% \mathrm{Cl})$ \\
\hline \multicolumn{6}{|l|}{ Sex } \\
\hline Boys & 401 & $140(34.91)$ & $261(65.09)$ & $6.84(4.32-11.17)$ & $7.25(4.33-12.71)$ \\
\hline Girls & 317 & $23(7.26)$ & $294(92.74)$ & 1 & 1 \\
\hline$x^{2}$ test & & & & 77.065 & - \\
\hline$P$-value & & & & $<0.0001$ & - \\
\hline \multicolumn{6}{|l|}{ Age (years) } \\
\hline $10-12$ & 126 & $22(17.46)$ & $104(82.54)$ & 1 & 1 \\
\hline $13-15$ & 485 & $107(22.06)$ & $378(77.94)$ & $1.34(0.81-2.26)$ & - \\
\hline $16-18$ & 94 & $29(30.85)$ & $65(69.15)$ & $2.11(1.11-4.01)$ & $4.43(2.62-7.49)$ \\
\hline $19-21$ & 11 & $4(36.36)$ & $7(63.64)$ & $2.70(0.64-10.08)$ & - \\
\hline $22-24$ & 2 & $1(50)$ & $1(50)$ & $4.73(0.12-185.89)$ & - \\
\hline$x^{2}$ test & & & & 0.642 & - \\
\hline$P$-value & & & & 0.4231 & - \\
\hline \multicolumn{6}{|l|}{ Address } \\
\hline Dutsin-Ma & 398 & $90(22.61)$ & $308(77.39)$ & 1 & 1 \\
\hline Safana & 320 & $73(22.81)$ & $247(77.19)$ & $1.01(0.71-1.44)$ & - \\
\hline$x^{2}$ test & & & & 0.004 & - \\
\hline$P$-value & & & & 0.9495 & - \\
\hline \multicolumn{6}{|l|}{ Altitude } \\
\hline $500-530 \mathrm{~m}$ & 312 & $55(17.63)$ & $257(82.37)$ & $1.69(1.18-2.45)$ & $1.27(0.87-1.88)$ \\
\hline $531-560 \mathrm{~m}$ & 406 & $108(26.61)$ & $298(73.39)$ & 1 & 1 \\
\hline$x^{2}$ test & & & & 8.083 & - \\
\hline$P$-value & & & & 0.0045 & - \\
\hline \multicolumn{6}{|l|}{ Fathers' occupation } \\
\hline Civil servants & 249 & $43(17.27)$ & $206(82.73)$ & 1 & 1 \\
\hline Farmers & 115 & $33(28.69)$ & $82(71.3)$ & $1.93(1.14-3.24)$ & $2.08(1.2-3.59)$ \\
\hline Other brown collar jobs & 351 & $87(24.79)$ & $264(75.21)$ & $1.58(1.05-2.39)$ & $1.42(0.92-2.23)$ \\
\hline Late (Dead) & 2 & $0(0)$ & $2(100)$ & 0 & - \\
\hline Retiree & 1 & $0(0)$ & $1(100)$ & 0 & - \\
\hline$x^{2}$ test & & & & 0.0001 & \\
\hline$P$-value & & & & 0.9921 & - \\
\hline \multicolumn{6}{|l|}{ Mothers' occupation } \\
\hline Civil servants & 76 & $7(9.21)$ & $69(90.79)$ & 1 & - \\
\hline Farmers & 2 & $0(0)$ & $2(100)$ & 0 & - \\
\hline Other brown collar jobs & 390 & $96(24.62)$ & $294(75.38)$ & $3.22(1.49-7.82)$ & - \\
\hline Housewives & 250 & $60(24)$ & $190(76)$ & $3.11(1.41-7.68)$ & - \\
\hline$x^{2}$ test & & & & 6.359 & - \\
\hline$P$-value & & & & 0.0117 & - \\
\hline Grand total & 718 & $163(22.7)$ & $555(77.3)$ & & \\
\hline
\end{tabular}

Abbreviations: COR Crude (unadjusted) odds ratio, $A O R$ adjusted odds ratio (indicated only for values with $P \leq 0.05$ ), $C l$ Confidence interval

researchers from Ethiopia [11] and Sudan [38]. An average civil servant is more likely to be literate than a peasant farmer. Where school children participate in farming activities with their illiterate and uninformed fathers, they suffered a higher risk of being infected. 
Boys were found to be seven times [AOR $(95 \% \mathrm{CI})$ : 7.3 (4.26-12.4)] more likely to be infected than girls. This is indeed rare in the literature. It could be explained by their involvement, to a very large extent, in various water contact activities than girls.

Cultural practices, coupled with the need to eke out a living as a result of the prevailing poverty may behaviourally predispose males to more contacts with open and potentially infested water bodies. Previous studies have documented males as having higher odds of being infected compared to females [11, 33, 39].

\section{Conclusions}

In this study, Dutsin-Ma and Safana in Katsina State, Nigeria, were classified as moderate-risk LGAs for genitourinary schistosomiasis. Age, sex, fathers' and mothers' occupations were identified as the determining epidemiological factors in the prevalence of the disease. Sustainable chemotherapeutic intervention with Praziquantel $^{\circledR}$ is highly recommended to reduce its prevalence below the threshold of public health significance. To compliment this, a good network of treated pipe-borne water, health education and waste disposal facilities should be urgently but adequately provided.

\begin{abstract}
Abbreviations
AOR, Adjusted odds ratio; Cl, Confidence interval; $\mathrm{CL}$, Confidence level; $C O R$, Crude odds ratio; LGAs, Local government areas; LGEA, Local government education authority area; OR, Odds ratio; SD, Standard deviation; SPSS, Statistical package for social sciences

\section{Acknowledgements \\ The authors sincerely acknowledge the support of the Director, Zonal Education Authority, Dutsin-Ma who was in charge of the High schools in the study LGAs. The cooperation of all the principals as well as staff of selected schools is held in high esteem. Special thanks to the amiable respondents for their splendid contribution to the success of the study. The effort of Dr Akinluyi Francis, Department of Remote Sensing and GIS, School of Earth and Mineral Sciences, Federal University of Technology, Akure, Ondo State, Nigeria in preparing the maps of the study area is highly acknowledged.}

\section{Funding}

This study did not receive funding from any organization or funding body. Rather, it was self-sponsored.

\section{Availability of data and materials}

The data used to arrive at the conclusion of this paper are part of a large data set. However, they will be made available upon a request directed to the corresponding author.

\section{Authors' contributions}

The study was conceived and designed by TEA while UL participated in the field and laboratory work with him. SI participated in preparing the manuscript. Statistical analysis was carried out by TEA. All authors read and approved the final version of the manuscript.

\section{Competing interests}

The authors declare that they have no competing interests.

\section{Ethics approval and consent to participate}

Written permission was addressed to the principals of the schools enrolled for the study by the ethical committee of the Zonal Office overseeing the affairs of the secondary schools in the study area. The purpose of the study was explained to the principals who fully concurred by assigning some staff members to assist in interviewing the respondents. Generally, students who consented to participate in the study were given orientation about the survey to enhance maximum cooperation needed. Letters of appreciation including the list of students suffering from the disease were handed over to the principals. Mass drug administration, in consultation with the State Ministry of Education, via the Zonal Office, was recommended. It is pertinent to state that arbitrary drug administration after research is not allowed in the study area due to the need to manage some sentiments peculiar to the people.

\section{Author details}

${ }^{1}$ Department of Biological Sciences, Faculty of Science, Federal University, Dutsin-Ma, P.M.B. 5001, Dutsin-Ma, Katsina State, Nigeria. ${ }^{2}$ Federal College of Education, P.M.B. 3045, Gwale Local Government, Kano State, Nigeria.

Received: 7 January 2016 Accepted: 28 June 2016

Published online: 07 July 2016

\section{References}

1. World Health Organization. Schistosomiasis: number of people treated, 2009. Wkly Epidemiol Rec. 2011;9(86):73-80.

2. Amuta EU, Houmsou RS. Prevalence, intensity of infection and risk factors of urinary schistosomiasis in pre-school and school aged children in Guma Local Government Area, Nigeria. Asian Pac J Trop Med. 2014;7:34-9.

3. World Health Organization. Schistosomiasis: population requiring preventive chemotherapy and number of people treated in 2010. Wkly Epidemiol Rec. 2012;87:37-44.

4. World Health Organization. Working to overcome the global impact of neglected tropical diseases: first WHO report on neglected tropical diseases. Geneva: WHO; 2010. p. 132.

5. Neglected Tropical Diseases. The burden of schistosomiasis. Available at http://www.cdc.gov/globalhealth/ntd/diseases/schisto_burden.html. Accessed on 9 October 2015.

6. Hotez PJ, Kamath A. Neglected tropical diseases in Sub-Saharan Africa: review of their prevalence, distribution and disease burden. PLoS Negl Trop Dis. 2009;3:e412.

7. National Bureau of Statistics. Annual abstract of statistics, Federal Republic of Nigeria 2011, 698 pp. Available at: http://www.nigerianstat.gov.ng/report/187. Accessed 23 June 2016.

8. Abaje BI, Sawa BA, Ati OF. Climate variability and change, impacts and adaptation strategies in Dutsin-Ma Local Government Area of Katsina State, Nigeria. J Geog Geol. 2014;6(2):1916-9779.

9. United Nations Environment Programme. Integration assessment of the impact of trade liberalization- A Country Study on the Nigerian Rice Sector. UNEP/Earthprint 2005; 107 pp. Available at http://www.unep.ch/etb/ publications/intassessment/nigeria.pdf. Accessed 30 June 2016.

10. Senghor B, Diallo A, Sylla SN, Doucouré S, Ndiath MO, Gaayeb L, et al. Prevalence and intensity of urinary schistosomiasis among school children in the district of Niakhar, region of Fatick, Senegal. Parasit Vectors. 2014;7:5.

11. Geleta S, Alemu A, Getie S, Meconnen Z, Erko B. Prevalence of urinary schistosomiasis and associated risk factors among Abobo Primary School children in Gambella Regional State, Southwestern Ethiopia: a cross sectional study. Parasit Vectors. 2015:8:215.

12. Ekpo UF, Laja-Deile A, Oluwole AS, Sam-Wobo SO, Mafiana CF. Urinary schistosomiasis among preschool children in a rural community near Abeokuta, Nigeria. Parasit Vectors. 2010;3:58.

13. European Centre for Disease Prevention and Control. Rapid risk assessment. Local transmission of Schistosoma haematobium in Corsica, France. Stockholm: ECDC; 2014.

14. World Health Organization. Prevention and control of schistosomiasis and soil-transmitted helminthiasis: report of a WHO expert committee. WHO Tech Rep Ser. 2002;912:1-57.

15. World Health Organization. Preventive chemotherapy in human helminthiasis: Coordinated use of anthelmintic drugs in control interventions: A manual for health professionals and programme managers, Geneva, 2006. Available at http://apps.who.int/iris/bitstream/10665/43545/1/9241547103_eng.pdf Accessed 23 June 2016. 
16. Akeh AM, Ejezie GC, Enyi-Idoh KH, Eja ME, Agba AO, Ogbeche JO. Urinary schistosomiasis, perception and treatment seeking behavior in Sankwala, Cross River State, Southeastern Nigeria. Nig J Parasitol. 2010;31:7-13.

17. Oniya MO, Olofintoye LK. The prevalence of urinary schistosomiasis in two endemic Local Government Areas of Ondo State. Nig J Parasitol. 2009;30:147-51.

18. Dawet A, Benjamin CB, Yakubu DP. Prevalence and intensity of Schistosoma haematobium among residents of Gwong and Kabong in Jos North Local Government Area, Plateau State, Nigeria. Int J Trop Med. 2012;7(2):69-73.

19. Reuben RC, Tanimu H, Musa JA. Epidemiology of urinary schistosomiasis among secondary school students in Lafia, Nasarawa State, Nigeria. J Biol Agric Healthc. 2013;3(2):73-83.

20. Bello A, Jimoh AO, Shittu SB, Hudu SA. Prevalence of urinary schistosomiasis and associated haemato-proteinuria in Wurno rural area of Sokoto State, Nigeria. Orient J Med. 2014;26(3-4):114-21.

21. Kabiru M, Ikeh El, Aziah I, Julia O, Fabiyi JP, Muhamed RA. Prevalence and intensity of schistosoma haematobium infections: a community-based survey among school children and adults in Wmakko town, Sokoto State, Nigeria. Int J Trop Med Pub Health. 2013;2(1):12-21.

22. Singh K, Muddasiru D. Epidemiology of schistosomiasis in school-aged children in some riverine areas of Sokoto, Nigeria. J Public Health Epidemiol. 2014;6(6):197-201.

23. Kabiru M, Muhamed RA, Ikeh El, Aziah I, Julia O, Fabiyi JP. A multivariate analysis on the assessment of risk factors associated with infections and transmission of Schistosoma haematobium in some selected areas of Northwestern Nigeria. J Med Bioeng. 2015;4(1):7-11.

24. Nausch N, Dawson EM, Midzi N, Mduluza T, Mutapi F, Doenhoff MJ. Field evaluation of a new antibody-based diagnostic Schistosoma haematobium and S. mansoni at the point-of-care in northeast Zimbabwe. BMC Infect Dis. 2014;14:165.

25. Mtethiwa AHN, Nkwengulila G, Bakuza J, Sikawa D, Kazembe A. Extent of morbidity associated with schistosomiasis infection in Malawi: a review paper. Infect Dis Poverty. 2015:4:12.

26. Houmsou RS, Amuta EU, Sar T. Profile of an epidemiological study of urinary schistosomiasis in two local government areas of Benue state, Nigeria. Int J Med Biomed Res. 2012;1(1):39-48.

27. Ossai OP, Dankolil R, Nwodo C, Tukur D, Nsubuga P, Ogbuabor D, et al. Bacteriuria and urinary schistosomiasis in primary school children in rural communities in Enugu State, Nigeria. Pan Afr Med J. 2014;18(1):15.

28. Ibidapo CA, Mafe MA, Awobimpe OL. Comparison of three diagnostic methods for the determination of prevalence of urinary schistosomiasis among residents and pupils of Badagry area of Lagos State, Nigeria. Afr J Biotechnol. 2005;4(11):1325-8.

29. Uneke C, Oyibo P, Ugwuoru C, Nwanokwai A, lloegbunam R. Urinary schistosomiasis among school age children in Ebonyi State, Nigeria. Internet J Lab Med. 2006;2(1):1-7.

30. Ajayi JB, Sam-Wobo SO, Agbeyangi AO. Prevalence of urinary schistosomiasis in part of Ogun State, Nigeria. J Natural Sci Res. 2015;5(5):62-9.

31. Bakhit HA, Shanan S, Saad MB. The prevalence of Schistosoma haematobium among the population of Keryab village, Sharg el Nil, Khartoum North with emphasis on secondary bacterial infection. Sudan Med Lab J. 2011;1:36-46.

32. Balla HJ, Babagana I, Baba S, Ibrahim H. Incidence of urinary schistosomiasis among out-of-school pupils and almajiris in Dikwa, North Eastern Nigeria. Global J Med Res-C: Micro Path. 2015;15(2):8-14.

33. Clements ACA, Garba A, Sacko M, Toure S, Dembelé R, Landouré A, et al, Mapping the probability of schistosomiasis and associated uncertainty, West Africa. Emerg Infect Dis. 2008;14(10):1629-32.

34. Grimes JET, Croll D, Harrison WE, Utzinger J, Freeman MC, Templeton MR. The relationship between water, sanitation and schistosomiasis: a systematic review and meta-analysis. PLoS Negl Trop Dis. 2014;8(12):1-12.

35. Kanwai S, Ndams IS, Kogi E, Abdulkadir JS, Gyam ZG, Bechemagbor A. Cofactors influencing prevalence and intensity of Schistosoma haematobium infection in sedentary Fulani settlements of Dumbi, Igabi LGA, Kaduna State, Nigeria. Sci World J. 2011;6(2):15-9.

36. Nwosu DC, Nwachukwu PC, Avoaja DA, Ajero CMU, Nwanjo HU, Obeagu El, et al. Index of potential contamination for urinary schistosomiasis in Afikpo North L.G.A., Ebonyi State, Nigeria. Eur J Biomed Pharm Sci. 2015; 2(1):439-50.
37. Mfur AY, Lukong CS, Ogbu D. Determinants and prevalence of schistosomiasis in a Primary School in Benue State, Nigeria. West Afr J Nurs. 2011;22(1):1-13.

38. Abou-Zeid AH, Abkar TA, Mohamed RO. Schistosomiasis infection among primary school students in a war zone, Southern Kordofan State, Sudan: a cross-sectional study. BMC Public Health. 2013;13:643.

39. Brooker S, Beasley M, Ndinaromtan M, Madjiouroum EM, Baboguel M, Djenguinabe $E$, et al. Use of remote sensing and a geographical information system in a national helminth control programme in Chad. Bull World Health Organ. 2002;80(10):783-9.

\section{Submit your next manuscript to BioMed Central and we will help you at every step:}

- We accept pre-submission inquiries

- Our selector tool helps you to find the most relevant journal

- We provide round the clock customer support

- Convenient online submission

- Thorough peer review

- Inclusion in PubMed and all major indexing services

- Maximum visibility for your research

Submit your manuscript at www.biomedcentral.com/submit
Biomed Central 